\title{
PENINGKATAN MUTU KINERJA PRAJURIT TNI-AD RAIDER 631 YONIF ANTANG DALAM BIDANG ADMINISTRASI PERKANTORAN DI PALANGKA RAYA
}

\section{IMPROVEMENT OF THE PERFORMANCE OF THE TNI AD RAIDER 631 YONIF ANTANG IN OFFICE ADMINISTRATION IN PALANGKA RAYA}

\author{
Maura Widyaningsih ${ }^{1)}$, Sulistyowati ${ }^{2)}$ \\ Prodi Teknik Informatika ${ }^{1,2)}$, STMIK Palangka Raya \\ Jl. George .Obos No. 114 Palangka Raya \\ ${ }^{1}$ maurawidyaegmail.com \\ ${ }^{3}$ stykirenina@gmail.com
}

Abstrak

Penguasaan teknologi menuntut setiap prajurit/ anggota TNI-AD pemegang peranan administrasi perkantoran untuk dapat memanfaatkan dalam mendukung pelayanan dan perbaikan kinerja dalam tata kelola di perkantoran Komando Resor Militer 102/ Panju Panjung Batalyon Infanteri Raider 631 Antang . Hingga saat ini perkembangan fasilitas dan dukungan software office dalam memudahkan tata kelola dokumen masih blum dapat dimanfaatkan secara maksimal dikalangan para Prajurit TNI-AD Asmil Raider 631 Yonif Antang. Faktor inilah yang memberikan peluang bagi pakar dalam bidang tehnologi untuk berperan membantu masyarakat dalam pendayagunaan teknologi sehingga mereka dapat memahami dan mengerti lebih lanjut tentang kemanfaatannya. Proposal ini diharapkan dapat memberikan kontribusi kepada masyarakat khususnya anggota/prajurit TNI-AD untuk mengenal, memahami, menggunakan dan mempraktekan secara langsung kemanfaatan teknologi dalam mendukung penyelesaian permasalahan dokumentasi ataupun administrasi perkantoran. Pelaksanaan pelatihan dilakukan di Perkantoran Kantor Mayonif Raider 631 Antang terletak di Tjilik Riwut Km. 6 Palangka Raya dan masih berada diwilayah kota. Software dukung yang digunakan dan dimanfaatkan adalah Microsoft Office, yang merupakan sebuah sofware yang banyak menyediakan fasilitas dukungan dalam pengeolaan dokumen dan data yang merupakan salah satu kegiatan administrasi perkantoran. Melalui keluaran yang ingin dicapai pengusul maka masyarakat dapat memanfaatkannya Microsoft Office dan seluk beluknya dalam penanganan problem adminstrasi. Software Grafis akan mendukung desain gambar dan Software Browsher dan media Sosial yang mendukung komunikasi elektronik jarak jauh baik untuk pengiriman dokumen ataupun data. Perpaduan ketiga software aplikasi bantu tersebut yang perlu diperkenalkan pengelolaannya sehingga membantu kinerja administrasi perkantoran.Instruksi berikut merupakan panduan untuk mempersiapkan artikel untuk diterbitkan dalam Jurnal Pengabdian Masyarakat J-DINAMIKA.Gunakan dokumen ini sebagai template jika anda menggunakan Microsoft Word.

Kata Kunci - Peningkatan Mutu Kinerja Prajurit TNI , Bidang Administrasi Perkantora, Prajurit TNI-AD Raider.

Abstract

Mastery of technology requires every soldier / member of the TNI-AD who holds office administration roles to be able to take advantage of supporting services and improving performance in governance in the 102 / Panju Panjung Military Resort Command Office Antang Raider Infantry Battalion. Until now, the development of facilities and support for office software in facilitating document management is still not fully utilized among TNIAD Soldiers Asmil Raider 631 Yonif Antang. This factor provides an opportunity for experts in the field of technology to play a role in helping society in utilizing technology so that they can understand and understand more about its benefits. This proposal is expected to contribute to the community, especially members / soldiers of the TNI-AD to know, understand, use and directly practice the benefits of technology in supporting the resolution of problems with documentation or office administration. The training was held at the Office of Mayonif Raider 631 Antang, located at Tjilik Riwut Km. 6 Palangka Raya and still in the city area. Support software that is used and utilized is Microsoft Office, which is a software that provides many support facilities in managing documents and data which are one of the office administration activities. Through the output the proposer wants to achieve, the public can take advantage of Microsoft Office and its details in handling administrative problems. Graphic software will support image design and Browsher software and social media that support long-distance electronic communication for both sending documents and data. The combination of these three application software tools that need to be introduced to the management so that it helps the performance of office administration. The following instructions are a guide for preparing articles for publication in J-DINAMIKA Community Service Journal. Use this document as a template if you use Microsoft Word.

Keywords - Improving the Performance Quality of TNI Soldiers, Office Administration Division, TNI-AD Raider Soldiers. 


\section{I.PENDAHULUAN}

Kemajuan teknologi komputer membuat aktivitas menjadi serba cepat serta menjadikan dunia seperti tanpa batas. Berbagai jenis informasi dapat diakses dengan cepat dan akurat. Keberadaan teknologi menjadi suatu hal yang tidak biasa bagi masyarakat, permasalahan ini terkait dengan kurangnya human skill [1]. Keberadaan infrastruktur teknologi informasi yang baik dan memadai secara sarana maupun akses, secara tidak langsung dapat membawa masyarakat menuju information society, jika tidak dapat memanfaatkannya [2]. Pesatnya perkembangan teknologi informasi kini telah dimanfaatkan sebagian masyarakat di era indutri ke 4.0 adalah penggunaan teknologi informasi dalam berbagai hal untuk menyelesaikan suatu pekerjaan. Teknologi Informasi dan Komunikasi (TIK) bagi masyarakat dapat memberikan perubahan secara mendasar, terutama peningkatan kualitas kehidupan sering dianggap sebagai "individual empowering". Mewujudkan masyarakat modern yang tidak tertinggal dengan kondisi globalisasi, mendorong upaya pemerintah memajukan kualitas kehidupan warga negaranya melalui program-program pembangunan teknologi informasi hingga ke pelosok desa.[3]. Pemanfaatan komputer secara meluas dalam organisasi akan mendorong individu untuk menggunakan komputer dalam pekerjaannya.

Pemanfaatan komputer dilingkungan kerja diantaranya membuat surat dan juga untuk memenuhi kerja administrasi. Selain itu penggunaan komputer dapat memberikan pengaruh terhadap kinerja, kerja akan lebih mudah dan lebih cepat karena pekerjaan yang sudah pernah dilakukan otomatis sudah tersimpan. Dengan demikian, adanya penggunaan komputer secara luas dalam organisasi akan berguna dalam menyelesaikan serangkaian pekerjaan [4].

Pelayanan yang baik menunjukan kualitas kinerja, hal ini dipengaruhi oleh latar belakang pendidikan dan juga etos kerja sumber daya manusia [5]. Semakin kritis masyarakat terhadap tuntutan kualitas layanan menunjukkan karakter masyarakat kita dewasa ini yang telah memiliki sikap mandiri, terbuka dan mampu berdemokrasi. Dalam rangka membangun kualitas kinerja staff / anggota yang efektif dan efisien, diperlukan waktu untuk memikirkan bagaimana mencapai kesatuan kerjasama dalam kinerja sebagai penunjang pekerjaan dan hasil yang dicapai dalam pengelolaan administrasi perkantoran. Organisasi akan berjalan lebih baik dan cepat jika salah satu bagian tatakelola administrasi pegwai berjalan lancar, tertib, dan tepat waktu.

Kantor Mayonif Raider 631 Antang TNI-AD merupakan salah satu unsur infrastuktur keamanan yang ada di wilayah Palangka Raya. Prajurit / anggota TNI-AD bahwasanya belum memiliki kemampuan lebih untuk mengoperasikan dan menggunakan kemanfaatan MS Office secara maksimal fungsional software untuk pengelolaan dokumen adminsitrasi, demikian juga dengan grafis dan internet.

Microsoft Office adalah software atau perangkat lunak yang dirancang untuk memudahkan tugas perkantoran. Dengan Microsoft Office kita bisa mengetik proposal, surat, laporan keuangan, presentasi, database karyawan, membuat logo dan lain-lain.

Software Grafis seperti Corell Draw , Paint Brush, dan Adobe Photoshop memudahkan dalam editting gambar, membuat banner, brosur, dan sebagainya. Sedangkan untuk menjalin komunikasi, menyampaikan informasi melalui media elektronik perlu dikenalkan internet sebagai media elektronik untuk mengirimkan email dan menjalin kerjasama melalui jaringan luas.

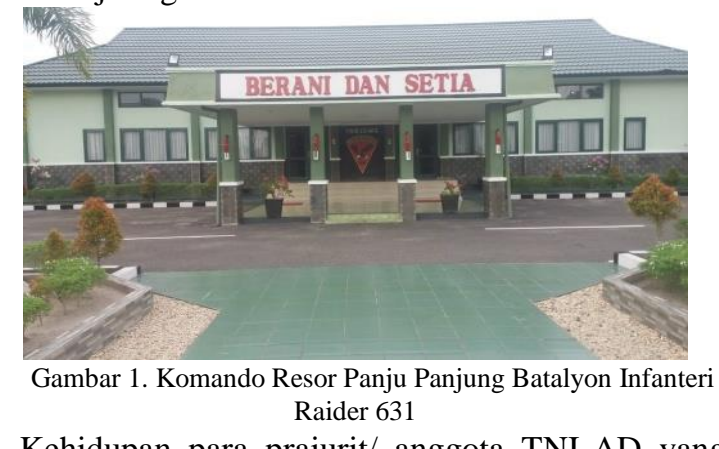

Kehidupan para prajurit/ anggota TNI-AD yang syarat dengan kewajiban menjaga keamanan dan ketertiban Negara, di jaman era teknologi tidak menutup kemungkinan untuk dapat mempelajari dan meningkatkan kinerja dengan melibatkan komputer sebagai media bantu. Pengelolaan adminsitrasi di jaman sekarang tidak lagi menggunakan proses konvensional yang lambat dengan layanan dan informasi. Berdasarkan hal tersebut setiap sumber daya manusia dituntut untuk dapat menggunakan teknologi sebagai media bantu dibidang administrasi perkantoran yang mendukung pekerjaannya.

Penggunaan komputer bagi kalangan prajurit / anggota TNI-AD tersebut belum dimaksimalkan, misalnya dalam pengelolaan surat, dokumen, laporan dan sebagainya yang berkaitan dengan permasalahan administrasi. Karena minimnya pemahaman tools yang tersedia di MS Office membuat cara menyusun dan mengelola dokumen administrasi perkantoran menjadi lambat. Disamping itu juga dikenalkan pemahaman tambahan mengenai seni grafis dengan menggunakan software grafis, dan mengenalkan pengelolaan media elektronik melalui internet. 


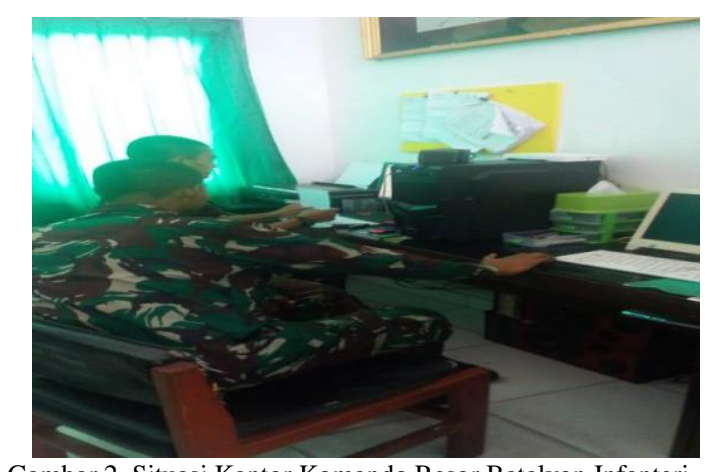

Gambar 2. Situasi Kantor Komando Resor Batalyon Infanteri Raider 631

Prajurit/ anggota TNI-AD TNI-AD Asmil Raider 631 Yonif Antang sebagian telah memiliki Laptop, namun smua belum maksimal digunakan. Dengan daya dukungan sarana mitra, maka akan sangat mendukung terhadap pelatihan dan pendampingan kemanfaatan teknologi komputer. Semua prajurit diharapkan dapat menguasai tehnologi sehingga meningkatkan mutu kinerja dalam tata kelola administrasi perkantoran, disamping tugas dan peranannya utamanya sebagai TNI. Dengan menguasai MS Office, Kelola grafis, dan media internet akan memberikan daya dukung peningkatan aktifitas dan pengetahuan serta wawasan di kalangan prajurit /anggota dalam tata kelola dokumen.

Berdasarkan analisis situasi yang telah diuraikan maka permasalahan yang dihadapi mitra saat ini yaitu prajurit/ anggota TNI-AD TNI-AD Asmil Raider 631 Yonif Antang adalah :

1. Keterbatasan pengetahuan prajurit / anggota Batalion Raider 631 TNI-AD dalam menggunakan dan memanfaatkan MS Office untuk pengelolaan administrasi perkantoran, sehingga masih lambat dalam penyajian laporan dan informasi di lingkungan Komando Resor Militer 102/ Panju Panjung Batalyon Infanteri Raider 631 Antang.

2. Kurang penguasaan Tools yang tersedia di MS Office, Software Grafis, dan media intenet sebagai bagian proses tindak lanjut administrasi untuk penginformasian lewat media elektronik jaringan.

\section{TARGET DAN LUARAN}

Berdasarkan permasalahan yang telah dipaparkan sebelumnya, bahwa kondisi staff/anggota Batalion Raider 631 TNI AD belum maksimal dalam penggunaan MS Office untuk pengelolaan administrasi perkantoran maupun dokumen lainnya. Hal ini diperlukan pelatihan dan pendampingan dalam pemanfaatan software MS Office dalam penerapannya terhadap tata kelola dokumen dan data yang berkaitan dengan administrasi perkantoran di lingkungan Komando Resor Militer 102/ Panju Panjung Batalyon Infanteri Raider 631 Antang. Perlu diketahui bahwa diantara prajurit / anggota telah memiliki beberapa sarana pendukung komputer ataupun lap top, namun sebagian besar belum memanfaatkan kehandalan MS Office dalam pengelolaan dokumen dan data secara praktis, serta software grafis dalam kelola grafis. Mereka mengharapkan dengan adanya pelatihan dan pendampingan dari pihak STMIK Palangka Raya, dapat memperoleh hasil dalam meningkatkan kemampuan penguasaan MS Office. Selain itu diharapkan pula sumber daya prajurit / anggota TNI_AD dapat meningkatkan kemampuan kinerjanya dan tidak gagap terhadap perkembangan teknologi dan tuntutannya dengan berwawasan teknologi untuk kemajuan tata kelola administrasinya. Sehingga penguasaan tombol dan tools dukung pada MS Office dapat dimengerti dan dipahami cara pemakaian dan penggunaannya secara maksimal. Dengan menguasai aplikasi kelola administrasi membuat invidu akan lebih kreatif dan inovatif pada pekerjaannya.

MS Office merupakan software atau perangkat lunak yang dirancang untuk memudahkan menyelesaikan tugas administrasi perkantoran. Paket-paket yang tersedia didalam MS Office seperti MS Word, MS Excel, MS Power Point, MS Access, MS Outlook dan MS Visio, dan yang lain. Bagi masyarakat perkantoran yang sering digunakan dalam pengelolaan administrasi perkantoran diantaranya MS Word, MS Excel, dan MS Power Point. Microsoft Word termasuk aplikasi yang paling sering digunakan, berfungsi untuk mengolah kata. Penggunaannya: dalam membuat surat, laporan, makalah, artikel, tabel, skripsi, dan lain-lain. Aplikasi Microsoft Excel adalah aplikasi yang berfungsi untuk mengolah angka/data dan disajikan dalam bentuk tabel atau grafik. Didalamnya tersedia fitur rumus yang dapat melakukan perhitungan secara otomatis, biasanya aplikasi ini digunakan oleh akuntan dalam membuat laporan keuangan. Aplikasi Microsoft Power Point adalah aplikasi yang berfungsi untuk membuat slide presentasi, aplikasi ini juga menyediakan fitur animasi yang dapat membuat presentasi menjadi lebih menarik. Software Grafis akan software dalam mendukung desain gambar dan Software Browsher dan media Sosial yang mendukung komunikasi elektronik jarak jauh baik untuk pengiriman dokumen ataupun data. Perpaduan ketiga software aplikasi bantu tersebut yang perlu diperkenalkan pengelolaannya sehingga membantu kinerja administrasi perkantoran.

Bentuk pelatihan pada prajurit TNI-AD yang dilakukan seperti Gambar 2. 


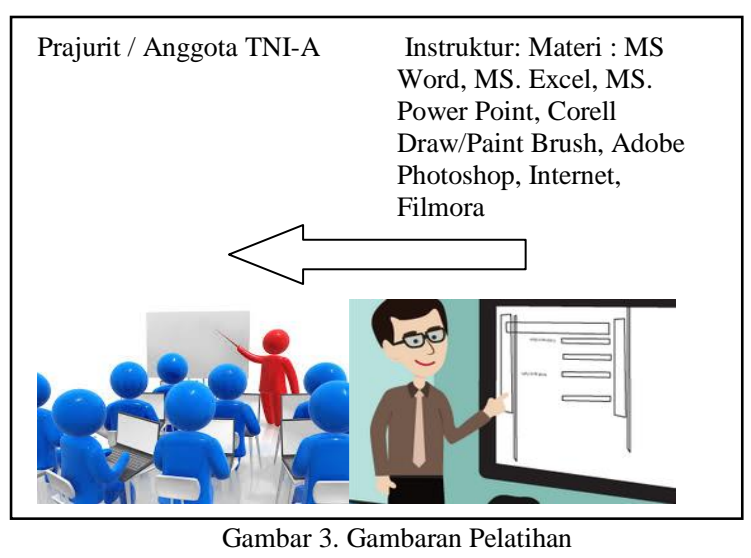

\section{A. Pengenalan Aplikasi Pengolah Kata}

Microsoft Word merupakan program aplikasi dari microsoft office yang biasa sering di gunakan untuk pengelolahan teks, pengelolahan dokumen, laporan dan lain sebagainya. sekarang hampir semua lapisan masyarakat menggunakan komputer terutama microsoft office word untuk aktifitasnya, seperti halnya siswa, guru, pekerja, pengusaha, dan hampir semuanya menggunakan office word untuk menunjang aktifitasnya.

Adapun fungsi dan kegunaan MS Word itu sendiri bervariasi /bermacammacam tergantung dari si user /pemakainya. Fungsi utama dari microsoft word adalah membantu kita dalam mengolah kata jadi seperti pengertian di atas Ms. Word memang di khususkan untuk pengolahan kata. MS Word berperan sebagai alat bantu user /pengguna untuk menyelesaikan pekerjaan terkait kata/teks/dokument/surat-menyurat dan lainya. Dengan semakin canggihnya tool microsoft word, fungsi dari ms word pun tidak hanya terbatas pada pengolahan kata. Tabel dalam MS Word juga bisa digunakan untuk olah angka meski tidak selengkap seperti di Microsoft Excel

Perkembangan MS Word sekarang adalah kemampuan lebih untuk penggunaan copy paste antar aplikasi di Microsoft Office sendiri, konversi dari file word ke pdf., dan masih banyak fitur tambahan Microsoft Word yang mendukung pengelolaan dokumen.

\section{B. Pengenalan Aplikasi Pengolah Data}

Microsoft Excel merupakan aplikasi untuk mengolah data secara otomatis yang dapat berupa perhitungan dasar, rumus, pemakaian fungsifungsi, pengolahan data dan tabel, pembuatan grafik dan menajemen data. Pemakaian rumus sendiri dapat berupa penambahan, pengurangan, perkalian dan lain sebagainya. Sedangkan pemakaian fungsi-fungsi dapat berupa pemakaian rumus yang bertujuan untuk menghitung dalam bentuk rumus matematika maupun non matematika. Ms Excel dapat juga digunakan untuk menyelesaikan berbagai keperluan administrasi, dari yang sederhana sampai dengan yang rumit. Pada pemakaian keperluan yang sederhana tersebut misalkan untuk membuat perencanaan kebutuhan suatu perusahaan, berupa perencanaan barang kebutuhan, jumlah maupun harganya.

\section{Pengenalan Aplikasi Pengolah Presentasi}

Perangkat lunak pengolah presentasi adalah suatu aplikasi yang digunakan untuk membuat file presentasi. Karena fungsinya sebagai alat untuk mengutarakan ide/gagasan, maka program presentasi harus memiliki tampilan yang menarik. Program presentasi dapat memasukkan objek-objek seperti gambar, video dan suara.

\section{Pengenalan Aplikasi Grafis}

Program ini sering digunakan untuk keperluan pembuatan brosur, pamflet, booklet, poster, dan sejenisnya. Aplikasi pengolah pixel/gambar dimanfaatkan untuk mengolah gambar/manipulasi foto (photo retouching). Semu objek yang diolah dalam progam-program tersebut dianggap sebagai kombinasi beberapa titik/pixel yang memiliki kerapatan dan warna tertentu, misalnya, foto. Gambar dalam foto terbentuk dari beberapa kumpulan pixel yang memiliki kerapatan dan warna tertentu. Meskipun begitu, program yang termasuk dalam kelompok ini dapat juga mengolah teks dan garis, akan tetapi dianggapa sebagai kumpulan pixel. Objek yang diimpor dari program pengolah vektor/garis, setelah diolah dengan program pengolah pixel/titik secara otomatis akan dikonversikan menjadi bentuk pixel/titik. Program ini mampu mengatur penempatan teks dan gambar yang diambil dari program lain (seperti Adobe Photoshop).

Aplikasi pengolah vektor/Garis digunakan untuk membuat gambar dalam bentuk vektor/garis sehingga sering disebut sebagai Illustrator Program. Seluruh objek yang dihasilkan berupa kombinasi beberapa garis, baik berupa garis lurus maupun lengkung. Corell Draw termasuk dalam aplikasi pengolah vektor.

Aplikasi pengolah film/Video Program dapat dimanfaatkan untuk mengolah film dalam berbagai macam format. Pemberian judul teks (seperti karaoke, teks terjemahan, dan sebagainya) juga dapat diolah menggunakan program ini. Umumnya, pemberian efek khusus (special effect) seperti suara ledakan, desingan peluru, ombak, dan lain-lain juga dapat dibuat menggunakan aplikasi ini. Aplikasi untuk pengolah video dapat menggunakan Filmora atau Video Studio.

\section{E. Pengenalan Internet}

Internet merupakan jaringan luas yang saling terkoneksi dari jaringan-jaringan komputer yang menghubungkan orang-orang dan komputer- 
komputer diseluruh dunia, melalui telepon, satelit dan sistem-sistem komunikasi yang lain. Internet dibentuk oleh kumpulan jejaring komputer yang terhubung memberi jalan bagi seriap informasi (mulai dari text, gambar, audio, video, dan lainnya ) untuk dapat dikirim dan dinikmati bersama dengan kata lain bertukar informasi. Pemahaman kompresi terhadap data yang akan dikirim baik untuk dokumen text, gambar, video ataupun audio, sehingga file yang dikirim tidak berukuran besar, karena biasanya dokumen yang dikirim lewat internet dibatasi oleh ukuran tertentu. Browshing dengan menggunakan kata kunci yang sesuai sehingga list di Google menampilkan sesuai dengan yang dibutuhkan dalam meningkatkan pengetahuan dan pemahaman, misalnya berkaitan dengan tutorial ataupun informasi yang dibutuhkan pengguna.

\section{F. Desain Gambar dengan Program Grafis}

Desain grafis atau rancang grafis merupakan proses komunikasi menggunakan elemen visual, seperti tulisan, bentuk, garis, warna dan gambar yang dimaksudkan untuk menciptakan persepsi akan suatu pesan yang disampaikan tentang sesuatu. Bidang ini melibatkan proses komunikasi visual, yang memudahkan untuk ditambahkan ke dalam dokumen yang diperlukan.

Penggunaan desain grafis memiliki tujuan agar orang mengerti pesan yang ingin disampaikan melalui visual, sehingga diperlukan kemampuan kognitif sekaligus keterampilan visual dengan tepat dan mudah dimengerti.

Desain Grafis yang dikenalkan adalah berbasis Bitmap dengan menggunakan Adobe Photoshop, dan berbasis Vektor dengan Corell Draw. Grafis vektor adalah objek gambar yang dibentuk melalui kombinasi titik-titik dan garis dengan menggunakan rumusan matematika tertentu. Pengertian Grafis Bitmap Grafis Bitmap adalah objek gambar yang dibentuk berdasarkan titik-titik dan kombinasi warna. Gambar berbasis bitmap biasanya digunakan dalam mengedit gambar 3 dimensi, penggabungan beberapa gambar sehingga gambar menjadi lebih bermakna berbeda untuk sumber informasi baik untuk dokumen ataupun dukungan iklan, poster, video dan sebagainya. Gambar berbasis vector biasa digunakan untuk gambar atau design yang membutuhkan fleksibilitas. Artinya design tersebut bisa digunakan dalam berbagai kesempatan, dalam berbagai ukuran, dan dalam berbagai media reproduksi. Misalnya dalam pembuatan logo. Logo digunakan untuk berbagai keperluan, mulai dari kop surat, kartunama, booklet dan banyak lagi.

\section{G. Editting Video}

Pengeditan video adalah manipulasi dan pengaturan pengambilan video/ gambar. Manipulasi merupakan proses untuk melakukan penggabungan, pemotongan / pemenggalan, penambahan unsur visual seperti efek transisi, background teks atau gambar maupun audio. Pengeditan video digunakan untuk menyusun dan menyajikan semua informasi video, termasuk film dan acara televisi, iklan video, dan esai video. Pengambilan sebuah video atau gambar dapat menggunakan kamera mobile ataupun kamera tunggal demikian juga dengan video. Program bantu yang digunakan dan mudah didapat adalah dengan menggunakan Filmora.

Melihat perlunya mempelajari dan menguasai aplikasi pendukung diatas adalah salah satu solusi ari pengembangan sumber daya manusia. Pengembangan merupakan usaha untuk meningkatkan kemampuan secara teknis, teoritis, konseptual, dan moral manusia menyesuaikan kebutuhan terhadap pekerjaan/jabatan melalui pendidikan dan pelatihan[6]. Development merupakan salah satu dari fungsi manajemen yang penting untuk memenuhi tuntutan pekerjaan sebagai akibat dari era globalisasi. Organisasi publik/pemerintah tidak terlepas dari pengaruh era globalisasi yang mengharuskan aparatur pemerintahan memberikan pelayanan sesuai dengan keinginan masyarakat.

Pendampingan dan pelatihan dilakukan untuk prajurit TNI-AD dimaksudlkan untuk memberikan edukasi mengenai pentingnya teknologi informasi dalam meningkatkan mutu kinerja administrasi di lingkungan kantor Komando Resor Militer 102/ Panju Panjung Batalyon Infanteri Raider 631 Antang. Pelayanan administrasi dilingkungan kantor akan lebih maju dan berkembang jika kinerja anggota kantor produktif secara teknologi.

\section{Metode PelaKsanAaN}

Kegiatan pengabdian Kepada Masyarakat yang akan dilaksanakan di Batalion Raider 631 TND-AD Antang adalah melalui beberapa langkah yang dapat digunakan untuk mmberikan solusi untuk mengatasi permasalahan yang ada. Adapun langkah-langkah yang akan dilaksanakan adalah sebagai berikut :

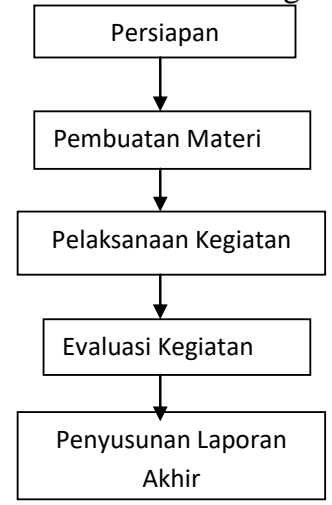

Gambar 4. Tahapan Pelaksanaan Program Pengabdian Masyarakat 


\section{H. Persiapan}

Melalui observasi awal / analisa permasalahan langsung ke Kantor Batalion Raider 631 TND-AD Antang Caro, dengan mengadakan wawancara dan observasi terhadap beberapa staff / anggotarnya. Melakukan wawancara dan observasi mengenai seputar pemahaman tehnologi, penggunaan, pengenalan dan penguasaan kemanfaatan aplikasi pada tata kelola dokumen, dengan membuat kuisioner analisis. Dari hasil observasi awal ditemukan permasalahan bahwa kurang pemahaman secara maksimal mengenai kemanfaatan tehnologi dan aplikasi dukung dalam pengelolaan dokumen administrasi. Dan sebagian mengalami kesulitan jika harus membuat dokumen administrasi secara cepat, karena keterbatasan pengetahuan yang dimilki. Prajurit / anggota TNI-AD telah memiliki beberapa sarana dukung berupa laptop, namun belum maksimal mengoperasikannya.Keterbatasan tutorial dan wawasan tehnologi menjadi kendala dalam menyelesaikan pekerjaan mereka, sehingga mengharapkan adanya jasa dari pihak STMIK Palangka Raya untuk dapat memberikan pendampingan dan pelatihan seputar pengelolaan dokumen administrasi dengan menggunakan MS Office.

Dari hasil observasi awal bahwa dari kuisioner yang disebarkan ke para prajurit yang akan diikutkan dalam pelatihan sejumlah 11 orang, hampir semua memiliki sarana pendukung komputer ataupun laptop. Penggunaan komputer sangat mendukung untuk proses kerja administrasi. Prajurit yang diikutkan dalam pelatihan berasal dari berbagai wilayah perwakilan di Kalimantan Tengah.

Hal ini dapat didasarkan pada hasil kuisioner terhadap pemahaman komputer kepada 11 prajurit, yang merupakan utusan dari masing-masing daerah seperti ditunjukkan pada Tabel 1.

\section{TABEL}

Acuan Ukuran Teks

\begin{tabular}{|c|c|c|c|c|c|}
\hline $\mathbf{P}$ & Pernyataan & $\begin{array}{l}\mathbf{T} \\
\mathbf{B}\end{array}$ & $\mathbf{S}$ & B & $\begin{array}{l}\mathbf{S} \\
\mathbf{B}\end{array}$ \\
\hline 1 & $\begin{array}{l}\text { Pemahaman Fungsi dan manfaat } \\
\text { dari aplikasi-aplikasi Office }\end{array}$ & 4 & 3 & 4 & \\
\hline 2 & $\begin{array}{l}\text { Pemahaman Fungsi dan manfaat } \\
\text { MS Word }\end{array}$ & 4 & 3 & 4 & \\
\hline 3 & $\begin{array}{l}\text { Pemahaman Fungsi dan manfaat } \\
\text { MS Excel }\end{array}$ & 4 & 4 & 3 & \\
\hline 4 & $\begin{array}{l}\text { Pemahaman Fungsi dan manfaat } \\
\text { MS Power Point }\end{array}$ & 2 & 6 & 3 & \\
\hline 5 & $\begin{array}{l}\text { Pemahaman dalam pengelolaan } \\
\text { kerja antar aplikasi Microsoft }\end{array}$ & 2 & 6 & 3 & \\
\hline 6 & $\begin{array}{l}\text { Pemahaman dalam melakukan kerja } \\
\text { manajemen file }\end{array}$ & 3 & 6 & 2 & \\
\hline 7 & $\begin{array}{l}\text { Pemahaman terhadap tata kelola } \\
\text { Layout dokumen }\end{array}$ & 2 & 5 & 4 & \\
\hline 8 & Pemahaman kelola style dokumen & 1 & 6 & 4 & \\
\hline 9 & $\begin{array}{l}\text { Pemahaman cara mencetak } \\
\text { dokumen }\end{array}$ & 1 & 3 & 7 & \\
\hline 10 & $\begin{array}{l}\text { Pemahaman dalam Pengelolaan } \\
\text { mail merger }\end{array}$ & - & 7 & 3 & 1 \\
\hline
\end{tabular}

\begin{tabular}{|c|l|c|c|c|c|}
11 & $\begin{array}{l}\text { Pemahaman dalam pengelolaan } \\
\text { grafik }\end{array}$ & 3 & 4 & 4 & \\
\hline 12 & $\begin{array}{l}\text { Pemahaman dalam pengelolaan } \\
\text { tabel }\end{array}$ & 2 & 6 & 3 & \\
\hline 13 & $\begin{array}{l}\text { Pemahaman dalam pengelolaan } \\
\text { formula (rumus-rumus) }\end{array}$ & 4 & 3 & 4 & \\
\hline 14 & $\begin{array}{l}\text { Pemahaman dalam pengelolaan } \\
\text { desain presentasi }\end{array}$ & 3 & 7 & 1 & \\
\hline 15 & $\begin{array}{l}\text { Pemahaman dalam pengelolaan } \\
\text { hyperlink }\end{array}$ & 3 & 6 & 2 & \\
\hline
\end{tabular}

Keterangan : $\mathrm{SB}=$ sangat bisa, $\mathrm{S}=$ sedikit, $\mathrm{B}=$ Bisa, $\mathrm{TB}=$ tidak bisa.

\section{Kemampuan Penggunaan Office}

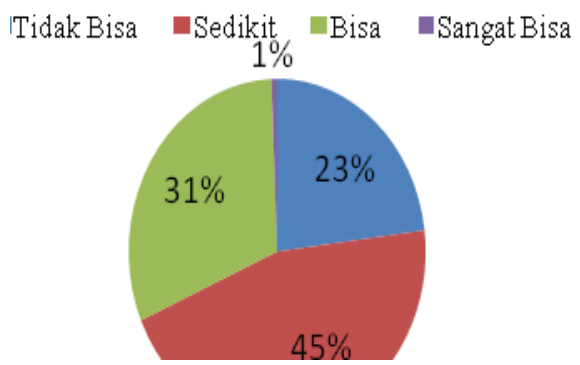

Gambar 2. Grafik pernyataan kuisioner

Berdasarkan dari data tersebut di atas bahwa dalam pemahaman penggunaan MS Office dalam pengelolaan Administrasi yang tidak bisa 23\%, sedikit memahami $45 \%$, yang bisa $31 \%$, dan yang sangat bisa hanya $1 \%$. Sedangkan untuk Internet dalam browshing, email dan penggunaan media sosial dalam berkirim pesan ataupun dokumen hampir $100 \%$ mengerti dan menguasai. Namun masih belum mengerti penggunaan internet untuk mencari pustaka-pustaka pengetahuan yang dibutuhkan dalam mengembangkan profesi dan aktifitas, demikian juga dengan kompresi data atau dokumen yang akan dikirim lewat email. Sedangkan untuk pengelolaan Grafis dan video editting hampir $100 \%$ tidak menguasai

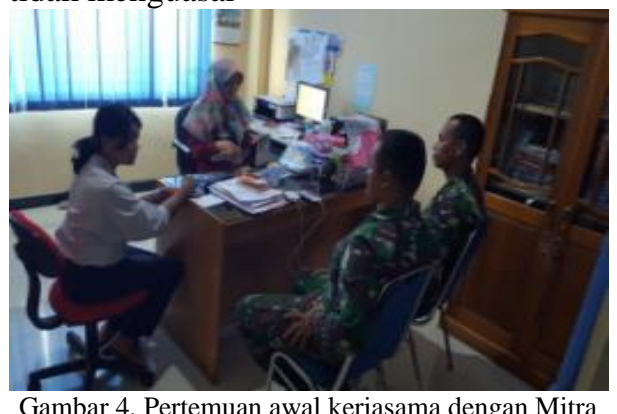

Gambar 4. Pertemuan awal kerjasama dengan Mitra 


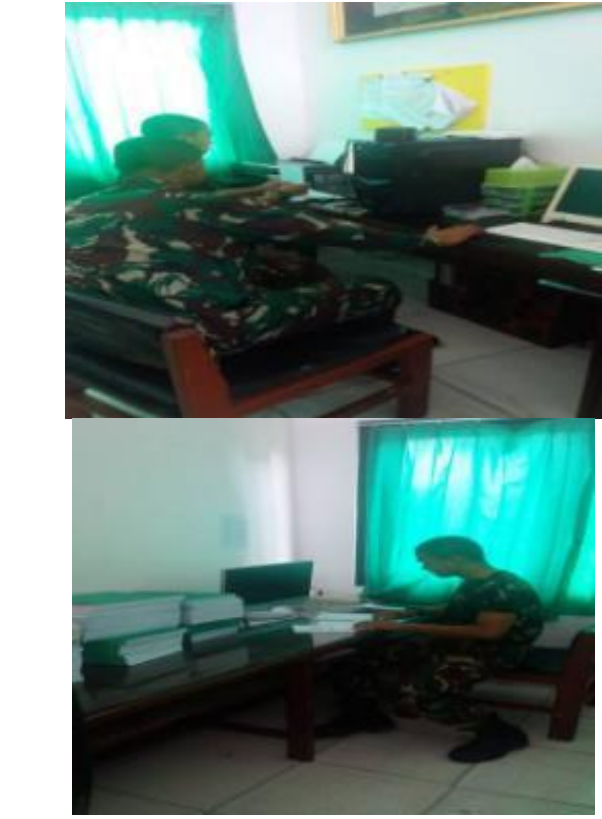

Gambar 5. Situasi Kantor Komando Resor Batalyon Infanteri Raider 631

\section{Penyusunan Materi / Modul Pelatihan}

Setelah mengetahui permasalahan diatas, maka sebelum melaksanakan pendampingan dan pelatihan perlu dilakukan persiapan materi / tutorial yang diperlukan baik berupa modul pelatihan ataupun juga video pembelajaran. Video pembelajaran dapat diambilkan dari berbagai sumber di internet ataupun dirancang pelaksana kegiatan. Materi seputar MS Word untuk kelola dokumen, MS Excel untuk kelola data, MS Power Point untuk kelola Presentasi dengan tambahan materi desain gambar dengan aplikasi Adobe Photoshop, Corell Draw atau dengan Paint. Desain gambar merupakan materi tambahan, karena kelola gambar dalam dukungan di dokumen. Materi-materi inti yang akan diberikan pada saat pelatihan adalah sebagai berikut :

1. Microsoft Word : pengenalan menu, pengenalan tools, mengelola surat, membuat daftar isi, bekerja dengan tabel, mengelola grafik/gambar, mengelola mail merger, membuat dokumen PDF, pengelolaan layout, latihan soal dan mencetak dokumen.

2. Microsoft Excel : Pengenalan sheet, pengenalan menu, pengenalan tools, bekerja dengan formula sederhana, membuat grafik, pengelolaan layout, latihan soal, membuat dokumen PDF dan mencetak dokumen.

3. Microsoft Powerpoint : membuat dan mendesain slide, bekerja dengan hyperlink, mengimputkan video, audio, dan gambar, mencetak presentasi.

4. Corel Draw, Pain Brush: mengenal tools, membuat / mengedit desain gambar sederhana (logo), mencetak gambar, mennyalin gambar ke dokumen.
5. Adobe Photoshop : mengedit ukuran gambar, menyalin gambar ke dokumen.

6. Internet : mengenalkan fungsi Browsher, Email, Drive, dan Media Sosial.

7. Editting Video : mengenalkan pengelolaan dasar dalam membuat dan mengedit video dengan aplikasi bantu untuk video editting.

\section{J. Pelaksanaan Kegiatan}

Kegiatan pengabdian ini dilaksanakan setelah persiapan materi, dengan waktu pelaksanaan selama 8 kali pertemuan secara intensif pagi dan sore. Pelatihan dilakukan di Ruang Pertemuan Komando Resor Panju Panjung Batalyon Infanteri Raider 631, dengan kapasitas 20 orang dilengkapi dengan LCD Proyektor. Gambar 6 menunjukkan susasan saat pelatihan dilaksanakan dengan personil utusan dari masing-masing daerah wilayah Komando Resor Panju Panjung Batalyon Infanteri Raider 631.

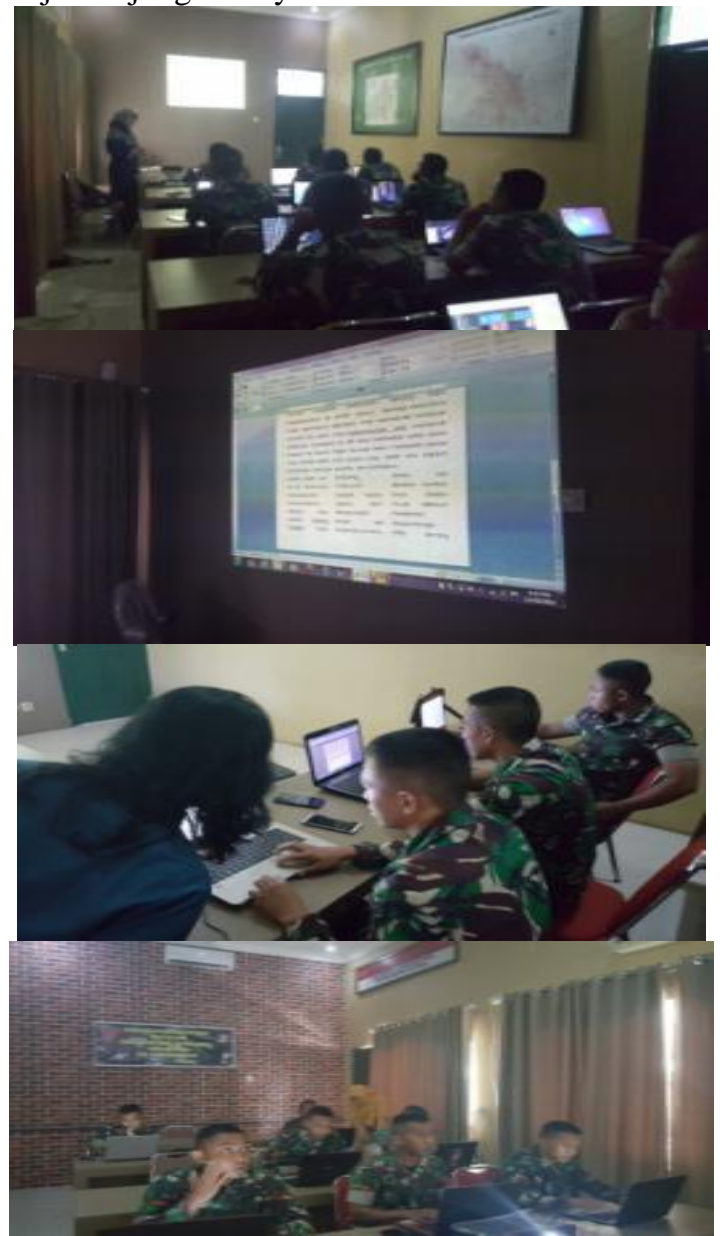

Gambar 6. Suasana Pelatihan di Ruang pertemuan pelatihan MS Office 


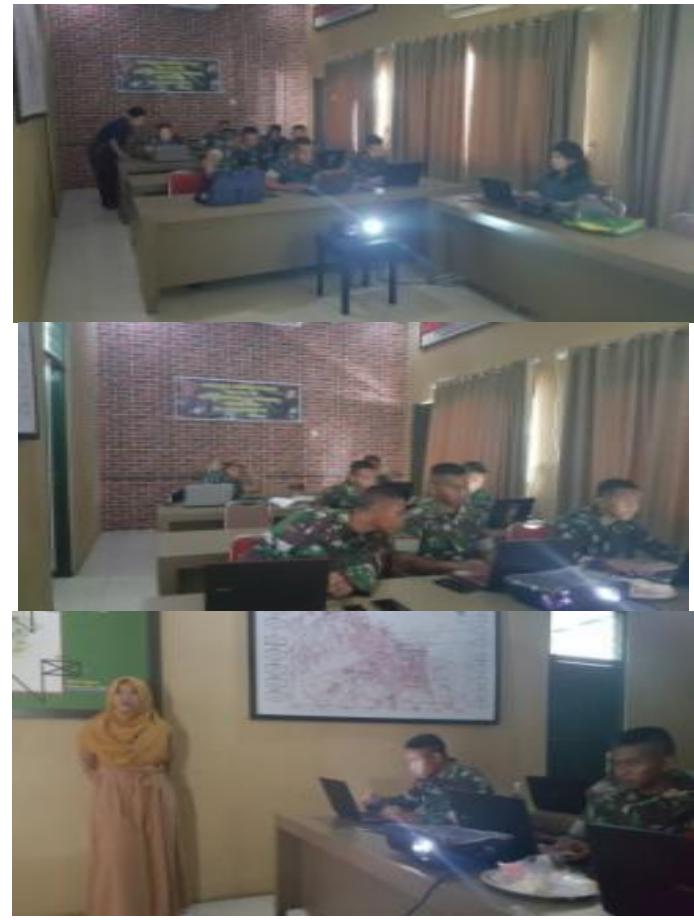

Gambar 7. Suasana Pelatihan di Ruang pertemuan pelatihan Desain Grafis dan Video Editting

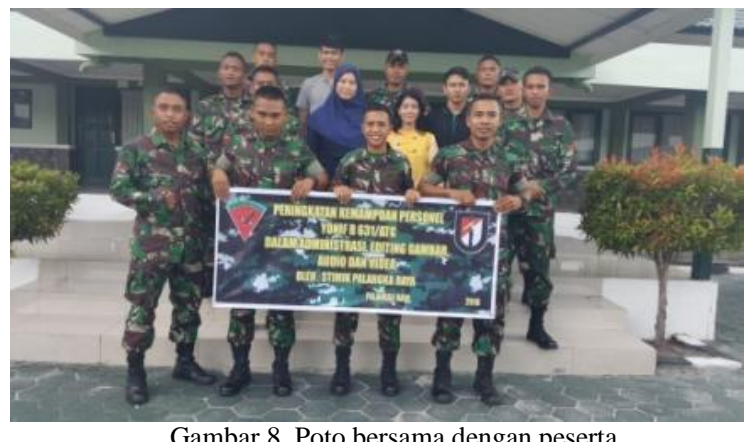

Gambar 8. Poto bersama dengan peserta

\section{K. Evaluasi Kegiatan}

Kegiatan Evaluasi ini bertujuan untuk melihat progress dari pelatihan di kalangan Prajurit / anggota TNI-AD dengan memberikan latihan akhir dari seluruh materi yang disampaikan. Bahan penilaian akhir dari latihan yang dibuat seputar pengelolahan dokumen dengan mail merger dengan MS Word, pengelolaan data dengan MS Excel, dan presentasi dengan MS Power Point, mengolah video, gambar, dan mengirim dokumen atau data elektronik lewat jaringan internet. Dari hasil review akan dapat diketahui pencapaian yang diterima oleh peserta pelatihan mengenai pemahaman tata kelola dokumen.

\section{Penyusunan Laporan Kegiatan akhir}

Didalam kegiatan ini adalah proses akhir dari kegiatan sebagai bukti bahwa kegiatan telah dilakukan dan diselesaikan. Sebagai wujud akhir dari pelaporan adalah sebagai berikut :

1. Menyusun dan melaporkan akhir hasil pelaksanaan kegiatan PKM dalam bentuk Laporan akhir

2. Menyusun draf publikasi kegiatan

3. Menerbitkan artikel publikasi

\section{HASIL DAN PEMBAHASAN}

Pelatihan dilaksanakan selama 8 hari dari pagi hingga sore di ruang pertemuan Batalyon Raider Antang Jl. Tjilik Riwut km 6.5. Modul pelatihan dan software dukung diberikan kepada peserta pelatihan dalam bentuk softfile.. Untuk kelanjutan luaran tambahan adalah jurnal pengabdian masyarakat.

Hasil evaluasi awal sebelum pelaksanaan pelatihan adalah sebagai berikut :

1. Peserta memiliki sarana dukung laptop dengan software office yang tersedia. Namun tidak ada software dukung untuk Grafis.

2. Sarana Laboratorium dengan dukungan Internet baik secara individu maupun dari ketersediaan Batalyon.

3. Kemampuan laptop yang tersedia dapat diinstalkan program-program tambahan untuk grafis.

Hasil yang dicapai dalam kegiatan ini adalah :

1. Pelatihan menggunakan MS Office mendukung dalam pengelolahan administrasi perkantoran, dengan memanfaatkan fasilitas kelola dokumen sehingga memudahkan dalam penyajikan laporan, grafik dan presentasi.

2. Pelatihan menggunakan Internet mendukung dalam pengambilan data, komunikasi elektronik dan pengiriman dokumen ke pihak lain secara cepat.

3. Pelatihan desain grafis mendukung dalam pembuatan grafis 2D, spanduk dan brosur yang diperlukan dalam kinerja kegiatan Antang.

4. Pelatihan video editting mendukung dalam aktivitas pengelolaan setiap kegiatan yang ada di Antang meliputi teknik capture, croping, dan rendering, seingga dapat menyajikan video dokumentasi.

Hasil evaluasi setelah pelaksanaan kegiatan pelatihan adalah sebagai berikut :

1. Peserta dapat menggunakan MS Office dengan memahami tools-tools praktis dalam mengelola dokumen, mengolah data, rumus, dan grafik sertamail merge. Untuk lebih mahir menggunakan materi dan mengembangkan kegunaan setiap peserta dibekali itutorial video dan materi sehingga dapat lebih membantu mengingat materi yang telah diajarkan. 
2. Peserta dapat mengelola data dengan formulaformula untuk perhitungandi MS Excel dengan latihan pengelolaan penggajian dan penjualan barang, disamping dapat membuat grafik data.

3. Peserta dapat menggunakan internet dalam mengambil gambar, data, tutorial, maupun email.

4. Peserta dapat membuat editting gambar, membuat simbol/logo sederhana dengan menggunakan tools dasar Corell Draw.

5. Peserta dapat mengolah beberapa editting gambar dengan menambahkan teks, gabungan beberapa gambar, latar belakang, dan lainnya dengan menggunakan Adobe Photoshop.

8. Peserta dapat melakukan video editting dengan menggunakan aplikasi Filmora dari hasil video dari hasil gambar atau rekaman video dari masing masing peserta, dengan menambahkan teks, skene, animasi layar dan latar belakang musik. Peserta juga dapat menguasai teknik capture, cropping, morphing dan rendering yang merupakan proses dalam video editting sehingga menghasilkan video dokumentasi kegiatan dengan beberapa efek tambahan.

\section{KESIMPULAN}

Kesimpulan yang dapat diambil dari kegiatan ini adalah :

1. Pelatihan menggunakan MS Office mendukung dalam pengelolahan administrasi perkantoran, dengan memanfaatkan fasilitas kelola dokumen sehingga memudahkan dalam penyajikan laporan, grafik dan presentasi.

2. Pelatihan menggunakan Internet mendukung dalam pengambilan data, komunikasi elektronik dan pengiriman dokumen ke pihak lain secara cepat.

3. Pelatihan desain grafis mendukung dalam pembuatan grafis 2D, spanduk dan brosur yang diperlukan dalam kinerja kegiatan Antang.

4. Pelatihan video editting mendukung dalam aktivitas pengelolaan setiap kegiatan yang ada di Antang meliputi teknik capture, croping, dan rendering, seingga dapat menyajikan video dokumentasi.

\section{UCAPAN TERIMAKASIH}

1. Terima kasih kami haturkan kepada STMIK Palangka Raya yang telah memberikan dukungan dana dan fasilitas transportasi sehingga kegiatan dapat berjalan dengan lancar.

2. Terima kasih kami sampaikan kepada Ketua STMIK Palangka Raya, yang telah memberikan persetujuan kegiatan ini dapat berjalan dengan baik.

3. Terimakasih kami sampaikan kepada komandan Resor Panju Panjung Batalyon Infanteri Raider 631di Palangka Raya yang berkenan memberikan kesempatan kepada pihak STMIK dalam kegiatan ini terutama penyambutan dan penyediaan sarana dan prasana sehingga dapat terlessaikan dengan lancar.

4. Terimakasih kami sampaikan kepada mahasiswa kami Andre dan Samani yang setia membantu mendampingi hingga akhir kegiatan sehingga dapat terlaksana tanpa kendala suatu apapun.

5. Terimakasih kami haturkan kepada semua pihak dalam dukungan doa.

\section{DAFTAR PUSTAKA}

[1] Badri, M. 2016. Pembangunan Pedesaan Berbasis Teknologi Informasi dan Komunikasi (Studi pada Gerakan Desa Membangun). Jurnal RISALAH, Vol. 27, No. 2, 6273.UIN

[2] Andiyansari, P. 2014. Studi Pemberdayaan Masyarakat Pedesaan Melalui Teknologi Informasi dan Komunikasi. Jurnal Penelitian Pers dan Komunikasi Pembangunan, 18 (2): 117-130

[3] Subiakto, H.. 2013. Internet untuk pedesaan dan pemanfaatannya bagi masyarakat. Masyarakat, Kebudayaan dan Politik, . 243-256

[4] Sabri . 2017. Kinerja Pegawai dan Kualitas Pelayanan Publik Pada Kantor Kendari. Fakultas Ilmu Administrasi Universitas Halu Uleo.

[5] Hidayat, A.. 2016. Kinerja Aparatur Dalam Meningkatkan Kualitas Pelayanan Masyarakat di Kelurahan Pelabuhan Kota Samarinda. eJournal Ilmu Pemerintahan, 4 (1) : $607-$ 618 ISSN 2477-2631, ejournal.ip.fisip.unmul.ac.id.

[6] Satriya D.B., Domai, T.., \& Suwondo. 2016. Pengembangan Sumber Daya Aparatur . Jurnal Administrasi Publik (JAP), 166-174. 